\title{
STUDY OF NATURAL MECHANISMS FOR THE SUPPLY OF TRANSPORTED MATERIALS TO THE AG. VARVARA COAST (LESVOS ISLAND)
}

\author{
Lykoudi E. ${ }^{1}$, and Antoniou M. ${ }^{1}$ \\ ${ }^{1}$ Department of Geological Sciences, School of Mining Engineering and Metallurgy, National \\ Technical University of Athens, 5 Heroon Polytechneiou St., 15780, Athens, Greece, \\ elykoudi@metal.ntua.gr
}

\begin{abstract}
The shaping of a coast is the result of the interaction of ground and marine factors. To study the formation mechanism of the coast, it is necessary to study both the characteristics of the source from which the transported materials originate, that is the rivers discharging in it, and the characteristics of the receiver of these materials, that is the coastal zone. The results of such a study contribute to the application of a administrative action plan to this system, based on the principles of the integrated administration and the viable evolution.

In this work the dynamics that shapes the coast of Ag. Varvara are examined. To this purpose, both the natural supply mechanism of the Ag. Varvara's coastal zone with materials from the Voulgaris river and the settlement mechanism of these materials are under investigation. The most significant factors influencing the characteristics of the Voulgaris river - which is the main materials supplier of the coast - and shaping the evolution of the Ag. Varvara's coatal zone, are the catchment area as well as the interactions taking place in it, the type and the quantity of the transported material, (geological factor), the tectonic movements influencing the shaping of the area, and finally the climatic conditions.

The geomorphologic-morphotectonic analysis points to the fact that, while there is substantial supply of material to the river bed, only a small percentage of that is being transported to the coast. This is attributing to the diminished transportation capability of the river. Other factors contributing to this are the longer than expected length of the river bed, its small slopes, an the low rainfall level in the area.
\end{abstract}

Key words: transported materials, Voulgaris river, Ag. Varvara coast, Lesvos, Greece.

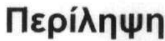

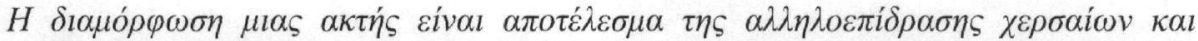

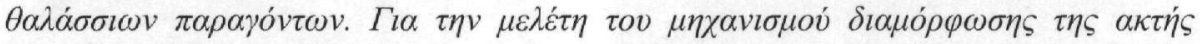

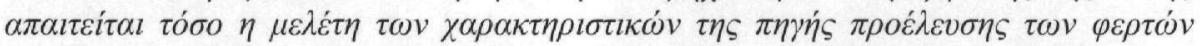

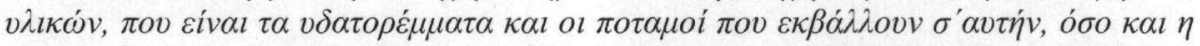

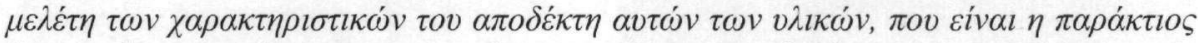

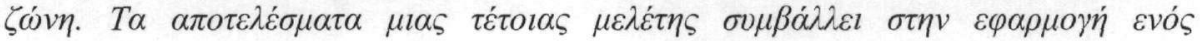




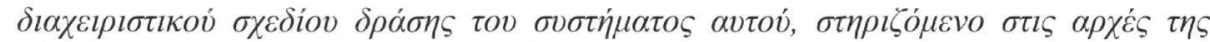

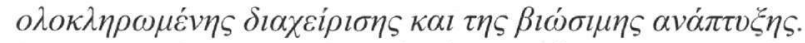

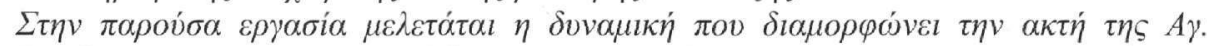

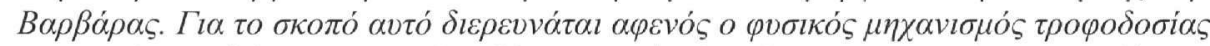

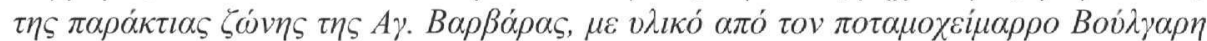

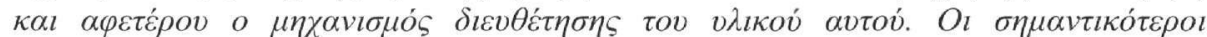

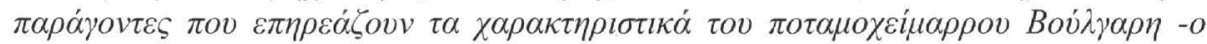

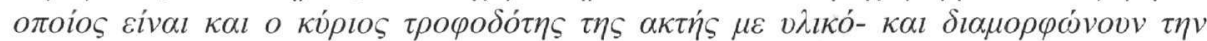

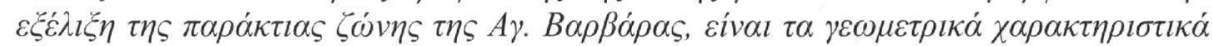

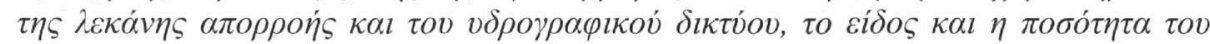

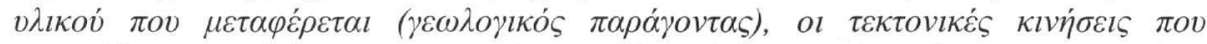

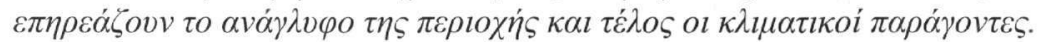

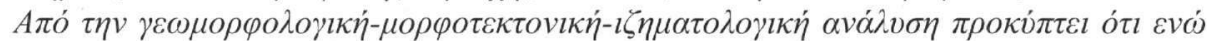

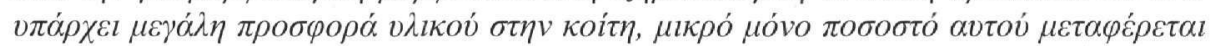

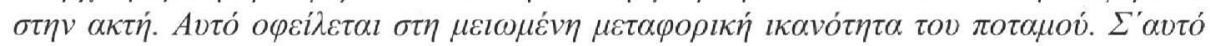

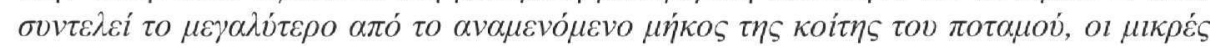

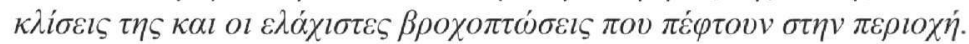

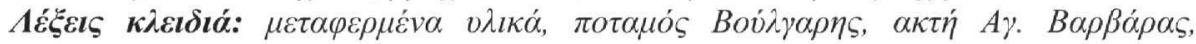
$\Lambda \dot{\varepsilon} \sigma \beta o \varsigma, E \lambda \lambda \dot{\alpha} \delta \alpha$.

\section{Introduction}

The Voulgaris river flows in the western region of the island of Lesvos. It's catchment area is $81.81 \mathrm{Km}^{2}$ and the river's main stream has a length of $14 \mathrm{Km}$. The drainage network is of the fifth order according to Horton and it has a dendritic and radial pattern. Noteworthy are the drainage network's asymmetry and its dislocation towards the west (Fig. 1). The river Voulgaris flows into the coast of Ag. Varvara, which has an E-W direction and a length of about $1 \mathrm{Km}$. East of the coast of Ag. Varvara lies the gulf of Gavatha and to its west the cape of Paleokastro.

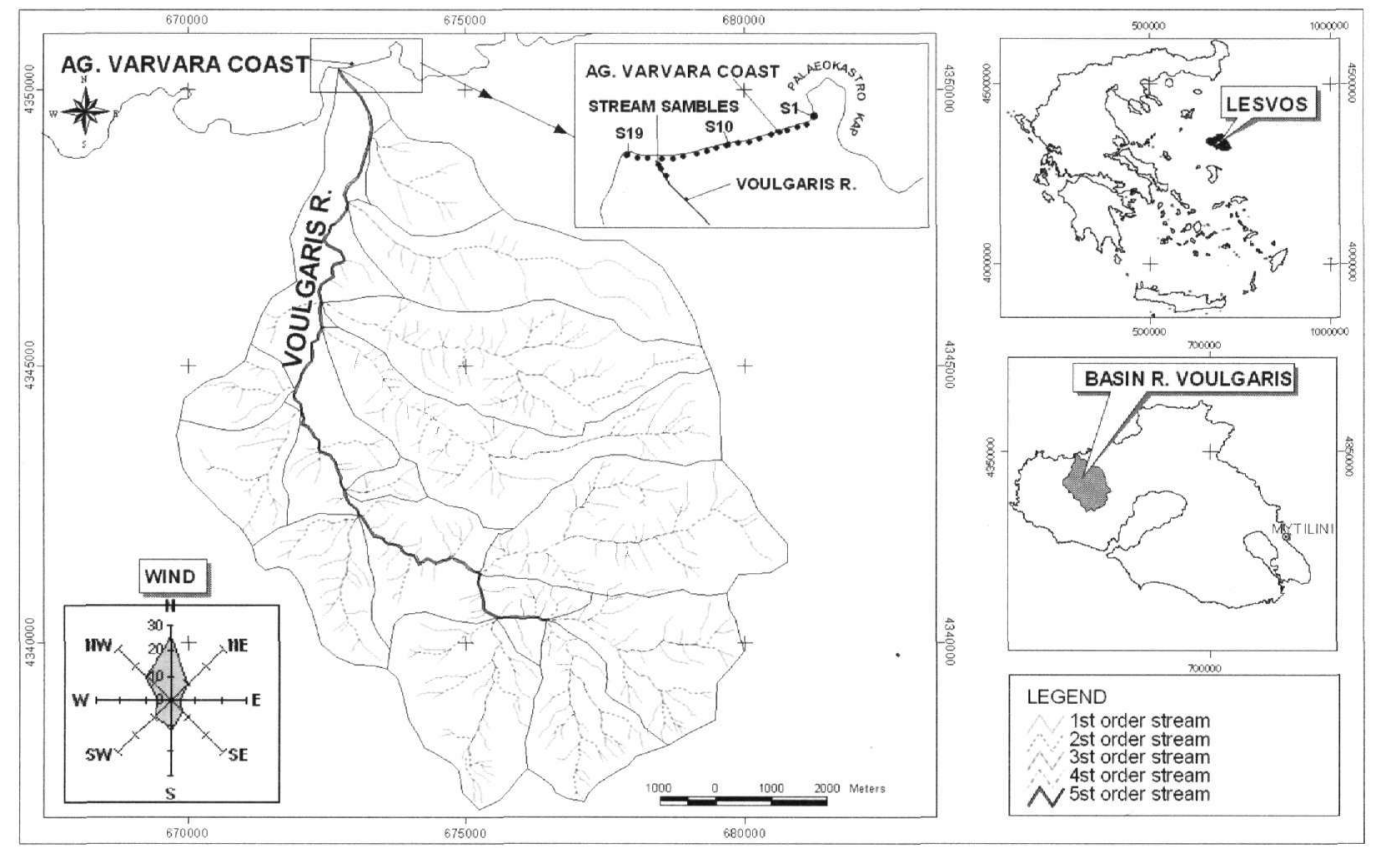

Figure 1 - Drainage network map of the Voulgaris river's basin 
The highest altitude $(700 \mathrm{~m})$ at the catchment area of the Voulgaris river as well as the steepest dip of the relief $(20 \%)$ are found at the south-east end of the basin where a dense drainage network as well as strong and in depth erosion are present (Fig. 3). The mean dip of the catchment area is about $8 \%$.

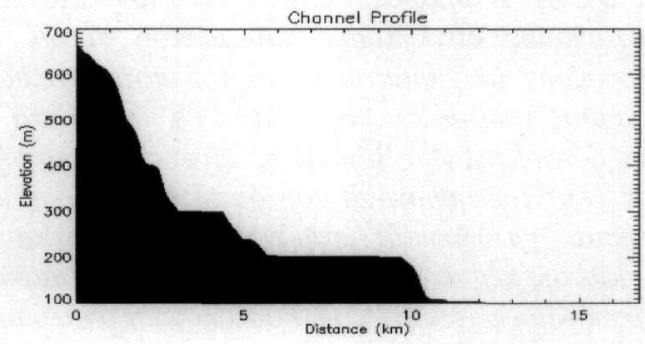

Figure 2 - Morphological section along the Voulgaris river

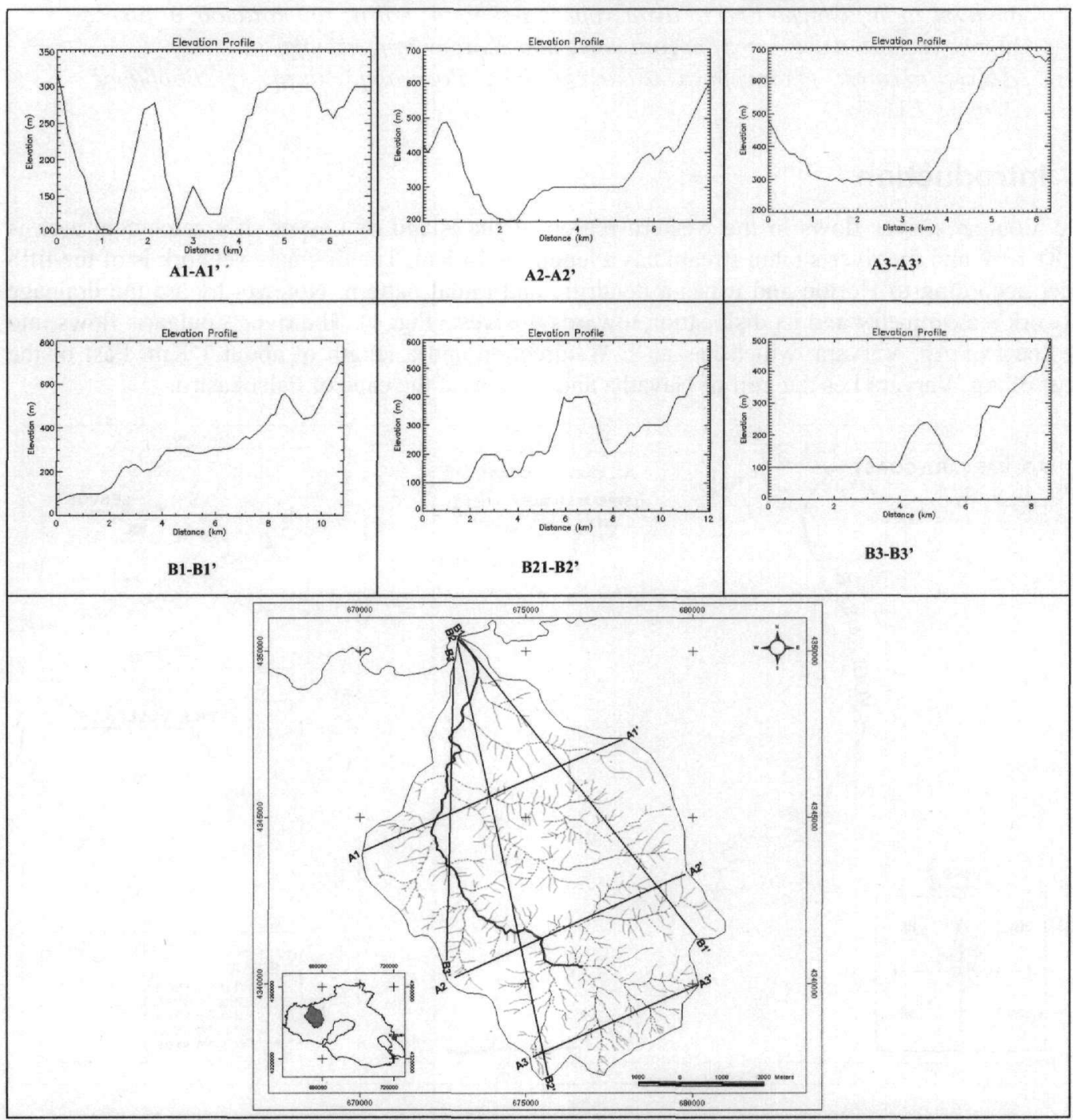

Figure 3 - Transverse and longitudinal morphological sections of the Voulgaris river's catchment area 
According to the geological maps of scale 1:50,000 (Hecht 1972, 1975), to Katsikathos et al. (1982, 1986) and Pe-Piper (1978), the area under investigation mainly consists of the recent volcanic sequence which in turn consists of alkaline basaltic effusions of lower Pliocene age, as well as of quarternary depositions. In some places, acid pyroclastic materials (ignimbrites, rhyolites etc) of the lower volcanic sequence are present. These formations found in the structure of the area under investigation generally belong to those which are easily eroded. In general, Lesvos is characterized by the presence of a mantle of rock-waste generally having considerable thickness and spreading on top of greatly fragmented rocks, which favour the formation of an abundant drainage network. This creates favourable conditions for extensive erosion and the production of transported materials accumulated on the lower parts of the slopes and drifted by the river (Alexouli-Livaditi et al. 2002). Three main fault systems are also remarked: one in NE-SW direction, which is the main cracks direction, one in NW-SE direction across which the longest cracks length is found, and finally one in N-S direction (Katsikatsos et al. 1982).

The western region of Lesvos belongs to the climatic type of semi-dry with low rainfall level during the winter and potential evapotranspiration between 855 and 995mm (Karras 1973)

From the meteorological data of the Hellenic National Meteorological Service station (the rainfall data are for the period 1969-1989 and those for the wind for the period 1955-1997) it appears that the summer in the island is hot and very dry while the winter is mild. There is a small surplus of water during the winter and during the rainy period streams are formed which supply the coasts with quantities of sediments. The average yearly rainfall for the period 1968-1989 was $657.7 \mathrm{~mm}$, while the month with the highest rainfall was January $(133.3 \mathrm{~mm})$ followed by December $(117.2$ $\mathrm{mm})$, February $(96.8 \mathrm{~mm})$, and March $(80.3 \mathrm{~mm})$. The months with the lowest rainfall were August $(2.7 \mathrm{~mm})$ and July $(3.0 \mathrm{~mm})$. The winds more frequently present during the whole year are the north winds $(25.23 \%)$ especially during the months of July and August. They are followed by the NW winds $(13.35 \%)$, the south winds $(11.22 \%)$ and finally the NE winds $(9.80 \%)$. There is also a considerable amount of calmness $(15.17 \%)$. The winds are generally mild, with a force of 2-4 Beaufort. $22 \%$ of the winds have a force of 2 Beaufort followed by those of 4 Beaufort $(21,4$ $\%$ ) and 3 Beaufort (20,9\%) (Fig. 1). The area under investigation is affected, due to its geographic position, by the waves created by the N-NW and west winds.

\section{Methodology}

For the present study, geomorphologic and geologic observations were carried out in the investigated area, while 19 samples collected across the coastline and three more from the river bed close to the river mouth. Laboratory analysis was carried out on all samples, like grain-size analysis, separation of light and heavy minerals in the 2-3 $\Phi$ fractions and definition of the mineralogical phases. This was followed by geomorphological analysis of the drainage network and the catchment area of the Voulgaris river during which data were collected, a data base was created, the data were processed and maps were constructed with the use of Geographic Information Systems (G.I.S). The quantitative analysis of the drainage network was done next, including: a) the calculation of the «bifurcation ratio», according to Horton 1945. The stream ordering of the drainage network has been done according to Strahler's (1957), b) the calculation of the «length ratio», according to Horton 1945, c) the calculation of the deviations of the real number and the real length of streams from the corresponding ideal values (Horton 1945), and d) the calculation of the «hypsometric integral» and «hypsometric curve», a parameter that expresses the denudation stage of a catchment area (Strahler 1952). The "hypsometric curve» shows in a simple way the distribution of the relief mass inside the basin.

During the geomorphological analysis, the directions of the streams per order as well as the faults were counted while rose diagrams were constructed and the "asymmetry factor" AF according to Hare and Gardner (1985) and the "transverse topographic symmetry factor", T, according to Cox (1994) were both calculated. 


\section{Geomorphological analysis}

The geomorphologic analysis studies the evolution of the catchment area of the Voulgaris river, the area where the weathering - erosion processes take place, resulting in materials transporting to the coast. For this reason, the parameters which form and influence the extent of the area and its morphology are calculated, as these data are necessary in order to study the mechanism supplying the coast of Ag. Varvara with materials. The morphotectonic structure of the catchment area is also examined as it is associated with erosion and deposition processes.

\subsection{Quantitative analysis of the drainage network}

The quantitative analysis of the drainage network was performed using the classic method by Horton (1945) and Strahler (1957). The drainage network of the river Voulgaris is of the 5th order and it includes 352 streams of the first order, 80 of the second, 18 of the third and 6 of the fourth order. At this stage, the quantitative analysis, as it was already mentioned, includes the calculation of the bifurcation ratio, the streams length ratio, and the percentage deviation of the real values of the number of streams from the ideal ones.

According to Shreve (1966) and Leopold and Langbein (1962), when the mean value of the bifurcation ratio $\left(R_{B}\right)$ of a drainage network is equal to the "theoretical" bifurcation ratio $\left(\mathrm{R}_{\mathrm{B}, \mathrm{TH}}=4,00\right)$ then, the drainage network is a dynamically balanced one, where the erosion, transportation and deposition processes alternate. For the drainage network under investigation, the mean value of the bifurcation ratio is $R_{B}=4,46$ (Table 1 ), a value which is higher than the "theoretical" one, meaning that the drainage network is in an unstable dynamically balanced state. This is due to the elevation of the relief attributed to the neotectonic processes taking place in the greater area under investigation, which may be amplified by a possible turgidity resulting from volcanic action.

The above are confirmed by the bifurcation ratio's value of the lower orders streams $\left(R_{B(1 / 2)}=4,40\right)$, which is higher than the value of the "theoretical" ratio, as well as by the even higher value of the higher orders ones $\left(\mathrm{R}_{\mathrm{B}(4 / 5)}=6,00\right)$. It must be noted that the former value is more related to the erosion processes, while the latter value mainly to the deposition but also to the transportation ones. The transportation processes mainly take place during flooding phenomena when at the same time the drainage of solid materials increases, an observation ascertained on the spot. Similar opinions are also expressed by Lykoudi and Zarris (2004).

Table 1 - Bifurcation ratio $\left(R_{B}\right)$ and Length ratio $\left(R_{L}\right)$

\begin{tabular}{|c|c|c|}
\hline Stream order & Bifurcation ratio $\left(\mathbf{R}_{\mathbf{B}}\right)$ & Length ratio $\left(\mathbf{R}_{\mathbf{L}}\right)$ \\
\hline $1^{\text {st }}$ & - & - \\
\hline $2^{\text {nd }}$ & $\mathrm{R}_{\mathrm{B}(1 / 2)=4.40}$ & $\mathrm{R}_{\mathrm{L}(2 / 1)=1.63}$ \\
\hline $3^{\text {rd }}$ & $\mathrm{R}_{\mathrm{B}(2 / 3)=4.44}$ & $\mathrm{R}_{\mathrm{L}(3 / 2)=2.11}$ \\
\hline $4^{\text {th }}$ & $\mathrm{R}_{\mathrm{B}(3 / 4)=3.00}$ & $\mathrm{R}_{\mathrm{L}(4 / 3)=1.83}$ \\
\hline $5^{\text {th }}$ & $\mathrm{R}_{\mathrm{B}(4 / 5)=6.00}$ & $\mathrm{R}_{\mathrm{L}(5 / 4)=6.37}$ \\
\hline Mean value & $\mathrm{R}_{\mathrm{B}=\mathbf{4 . 4 6}}$ & $\mathrm{R}_{\mathrm{L}}=\mathbf{1 . 8 6}$ \\
\hline
\end{tabular}

Another morphometric parameter, investigated in the present study, is the length ratio and in particular the one concerning the main river bed (stream of the $5^{\text {th }}$ order) over the streams of the immediately lower order. This is because, as it is already mentioned, there are two processes taking place on the Voulgaris' main river bed, those of transportation and deposition. The length ratio of the higher order streams of the drainage network under investigation has a high value $\left(R_{L(5 / 4)}=6,37\right)$ (Table 1). This is due to the long stretch of the stream of the $5^{\text {th }}$ order to which the $4^{\text {th }}$ 
order streams merge, with the latter having a satisfactory stretch. Therefore, the main river bed receives significant quantities of transported materials, and because of the long stretch of the river bed these materials are mainly deposited and transported during intense flooding phenomena.

Table 2 shows the deviations, in percentage, of the real values of the number of streams from the ideal values of the Voulgaris River. The small but negative deviation values show that only a small number and streams length is needed for the total real number of streams to reach the ideal values. This means that the drainage network did not have the time to develop the necessary number of streams with their corresponding length allowing the normal drainage of the catchment areas. As it is already mentioned, this is due to reformation of the drainage network from intense neotectonic actions together with a possible turgidity of the area due to volcanic action resulting in a deep erosion of the river's stream. It is also noted that the deviation value of the $4^{\text {th }}$ order number is positive and relatively high. This shows that the $4^{\text {th }}$ order streams are greater in number than the ideal stream number but they have an almost ideal length as indicated by the small deviation of the length value (Table 2). Consequently, the streams of this order, because of the higher number, can transport big quantities of transported materials to the river bed. Finally, it is noticed that the Voulgaris river bed has a length almost over than double that of the ideal one (length deviation of the $5^{\text {th }}$ order stream $=237.13 \%$ ), meaning that the river bed is able to receive a significant quantity of transported materials. As explained in chapter 3.2. the big length of the river bed results from its shift towards the west, especially of the central part, hence the increase of its course (Fig. 3).

Table 2 - Deviation of the real number, stream lengths from the ideal ones (\%)

\begin{tabular}{|c|c|c|}
\hline Stream order & Stream number & Mean stream length \\
\hline $1^{\text {th }}$ & -11.13 & 0.00 \\
\hline $2^{\text {th }}$ & -9.89 & -12.20 \\
\hline $3^{\text {rd }}$ & -9.55 & -0.13 \\
\hline $4^{\text {rd }}$ & 34.50 & -1.68 \\
\hline $5^{\text {rd }}$ & 0.00 & 237.13 \\
\hline
\end{tabular}

In Figure 4, the "hypsometric integral" (HI) of the Voulgaris river's catchment area is shown, indicating the denudation stage of the basin. From the shape of the curve, it is concluded that material is transported from the top of the basin (position A) and deposited towards the bottom of it, more at position $\mathrm{B}$ and less at position $\mathrm{C}$, while even less is transported to the coast (position D). This means that the basin is still capable of transporting materials to the coast since it is not in an advanced stage of denudation.

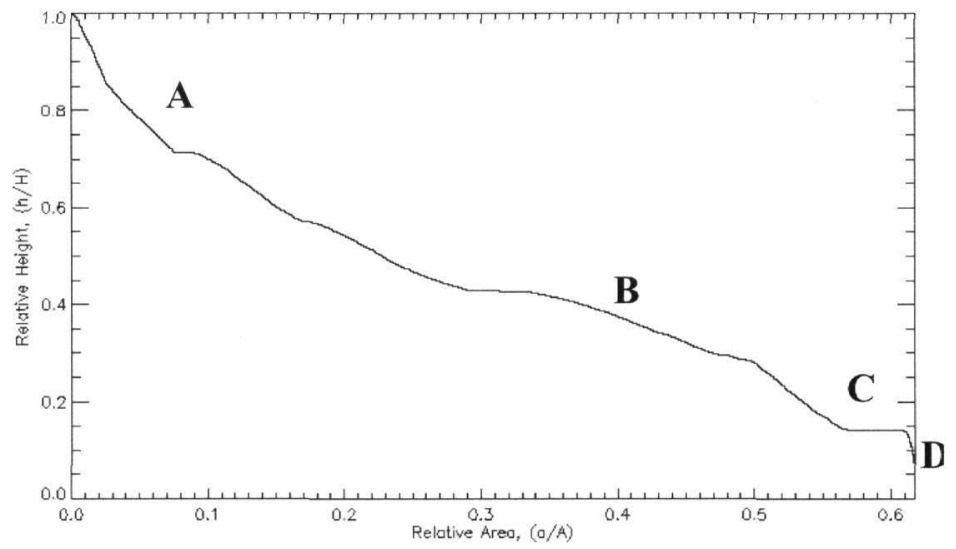

Figure 4 - Hypsometric curve 


\subsection{Morphotectonic analysis}

The morphotectonic analysis studies the influence of the endogenous forces (tectonic, volcanic) on the formation of the earth relief. Their influence is impressed on the form of the drainage network. In the framework of this study the morphotectonic analysis includes: a) the correlation of the streams directions per order with the directions of the faults in the greater area under investigation and $b$ ) the definition of the asymmetry factor (AF) and the symmetry factor $(\mathrm{T})$ of the drainage network.

The effect of the neo-tectonic action on the drainage network is noticeable, even at the present day, and it is confirmed by the directions of the streams which follow those of the faults (NE-SW and NW-SE) (Fig. 5). Consequently, the active tectonic of the Voulgaris river's catchment area designates the course of the river, hence the erosion and deposition processes taking place in the basin. These directions indicate that the drainage network is controlled mostly by the neo-tectonic action of the faults with directions NE-SW, and NW-SE (Alexouli-Livaditi and Lykoudi 2002).

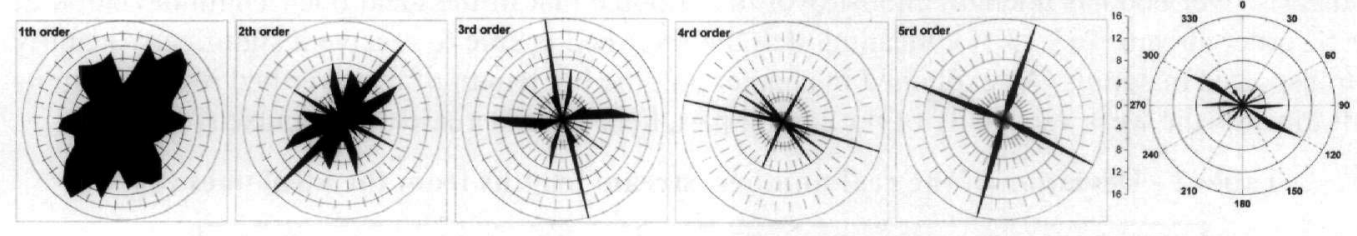

Figure 5 - Rose diagrams for all the orders streams of the of the Voulgaris' river drainage network, as well as the faults' rose diagram of the island of Lesvos

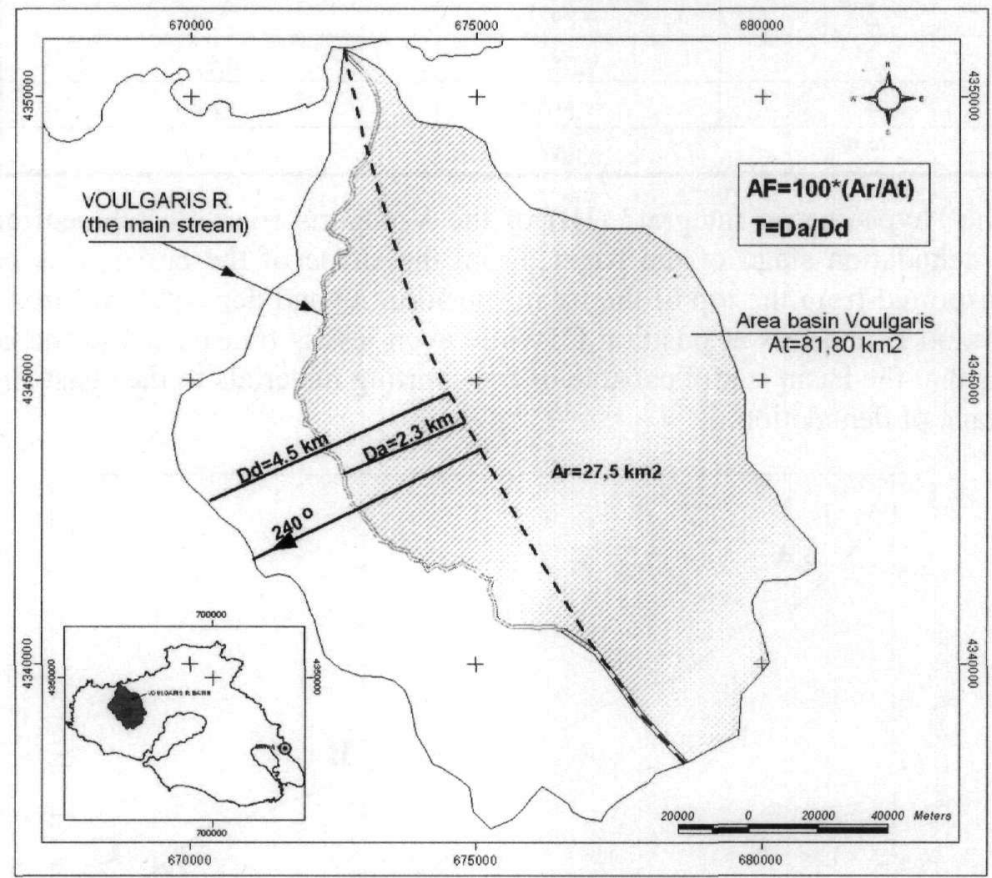

Figure 5 - Asymmetry Factors of the Voulgaris river [Asymmetry factor (AF) (Hare and Gardner 1985) and Tranverse Topographic Symmetry Factor (T) (Cox 1994)]

The single-slope structure of the catchment area of the Voulgaris river, calculated with the help of the asymmetry factor AF according to Hare and Gardner (1985) and the transverse symmetry factor T according to Cox (1994), indicates that the drainage network of the Voulgaris river is 
expanded on a tectonically active area. A possible rotation of the block-faulting results in an asymmetric expansion of the drainage network, therefore in a shift of the river bed towards the west, hence in the increase of its length as it is confirmed (Fig. 4). This is confirmed by the rose diagrams too (Fig. 5).

Table 3 - Asymmetry factor AF (Hare Gardner 1985), transverse symmetry factor T (Cox 1994) and asymmetry direction

\begin{tabular}{|l|c|c|c|}
\hline & $\begin{array}{c}\text { Asymmetry } \\
\text { Factor } \\
\text { (AF) }\end{array}$ & $\begin{array}{c}\text { Transverse Topographic } \\
\text { Symmetry Factor } \\
\text { (T) }\end{array}$ & $\begin{array}{c}\text { Asymmetry } \\
\text { Direction }\end{array}$ \\
\hline Voulgaris R. Basin & $33.6 \%$ & 0,51 & $240^{\circ}$ \\
\hline
\end{tabular}

\section{Sedimentary analysis}

It is important to know the current state of the coastal zone which is the final recipient of the river's transported materials, so that useful data for the mechanisms which disperse these materials can be derived.

The sedimentary study of the Ag. Varvara coast includes grain-size and mineralogical analysis of the coast sediments.

\subsection{Evaluation of the results of the grain-size analysis}

Evaluating the results of the grain-size analysis it is concluded that the sediments of the Ag. Varvara coast have a sandy texture. Based on the «mean size» fluctuating between 0,967 and $1,847 \Phi$ (mean value of the «mean size»=1,483 $\Phi$ ) (Table 4) and according to Folk (1974) the sediments of the Ag. Varvara coast belong to the lithological type of the medium-grain-size sand. From the grain-size analysis it is also ascertained that $56 \%$ of the samples analyzed are characterized as well sorted and the remaining $44 \%$ as moderately well sorted (Table 5).

According to Folk (1974) such grain-size data are indicative of an environment at a high hydrodynamic condition and poor supply of sediments. The N-NW and west strong winds blowing during the biggest part of the year in the area are responsible for high hydrodynamic energy, while the poor supply of sediments is linked to the low rainfall level and the petrologic structure of the rocks in the surrounding area, where the volcanic rocks are predominant.

The classification of the analyzed samples according to their skewness (SKI) shows that $78 \%$ of the sand samples exhibit near symmetric skewness and $22 \%$ fine positive skewness. This means that the highest percentage of the sand sediments have normal distribution and only $22 \%$ have a positive distribution, a fact denoting that only a small percentage of fine-grain-size material has been removed by waves and long shore currents from the sedimentation area (Spencer 1963). The kurtosis values of the granulous curve of the analyzed samples denote that their majority $(67 \%)$ is classified as mesokurtic - that is the sorting of the sand sediments is good in all size classifications - and secondary platykurtic and leptokurtic.

Typical accumulative curves of sand samples are presented in Figure 6.

\subsection{Mineralogical analysis}

The separation in light and heavy minerals done for fractions 2-3 $\Phi$ of sand samples from the Ag. Varvara coast confirms that the coast sand is particularly rich in heavy minerals. The percentage "mean value» of the heavy minerals participation is $69.201 \%$ and this high percentage must be related to the fact that the Voulgaris river falls into the coast and deposits material, rich in heavy minerals, probably transported from distant areas. Much higher $(93,833 \%)$ is the percentage of the heavy minerals participation in samples taken from deep in the river bed. 


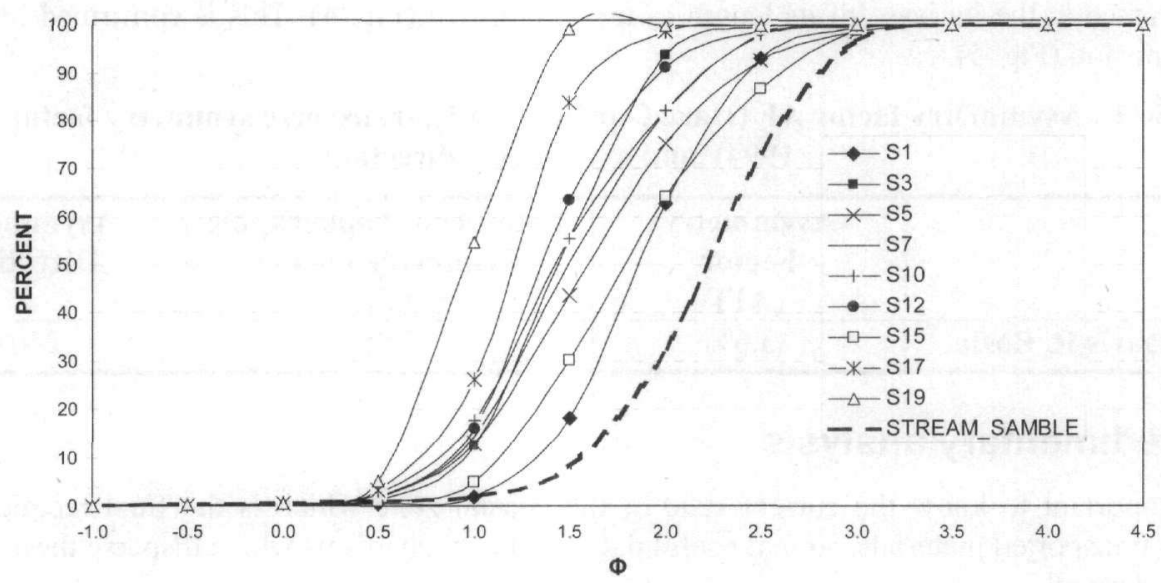

Figure 6 - Representative accumulative curves of sand samples of Ag. Varvara coast ( $\mathrm{S}=$ sample)

Table 4 - The range and mean value of the mean size Mz standard deviation $\sigma_{1}$ skewness SKI and kurtosis KG of the sand of Ag. Varvara coast

\begin{tabular}{|l|c|c|c|c|c|c|c|c|}
\hline \multirow{4}{*}{ Coast } & \multicolumn{2}{|c|}{ Mz } & \multicolumn{2}{c|}{$\boldsymbol{\sigma}_{1}$} & \multicolumn{2}{c|}{ SKI } & \multicolumn{2}{c|}{ KG } \\
\cline { 2 - 9 } & Range & $\begin{array}{c}\text { Mean } \\
\text { value } \\
\Phi\end{array}$ & Range & $\begin{array}{c}\text { Mean } \\
\text { value } \\
\Phi\end{array}$ & Range & $\begin{array}{c}\text { Mean } \\
\text { value }\end{array}$ & Range & $\begin{array}{c}\text { Mean } \\
\text { value }\end{array}$ \\
\hline AG. VARVARA & $0.967-1.847$ & 1.483 & $0.311-0.593$ & 0.453 & $-0.099-0.113$ & 0.023 & $0.794-1.259$ & 0.973 \\
\hline
\end{tabular}

Table 5 - Classification of the sand samples according to their standard deviation $\left(\sigma_{1}\right)$, the skewness (SKI) and to their kurtosis (KG), according to Folk (1974)

\begin{tabular}{|l|l|c|}
\hline \multirow{2}{*}{ coast } & \multicolumn{1}{|c|}{ AG. VARVARA } & $\%$ \\
\hline \multirow{2}{*}{$\sigma_{1}$} & Well sorted & 56 \\
\cline { 2 - 3 } & Moderately well sorted & 44 \\
\hline \multirow{2}{*}{ SKI } & Fine skewness & 22 \\
\cline { 2 - 3 } & Near symmetrical skewness & 78 \\
\hline \multirow{2}{*}{ KG } & Platykurtic curves & 22 \\
\cline { 2 - 3 } & Mesokurtic curves & 67 \\
\cline { 2 - 3 } & Leptokurtic curves & 11 \\
\hline
\end{tabular}

Table 6 - Quantitative composition in percentage of the sand samples of Ag. Varvara coast in light and heavy minerals at the fractions $2-3 \Phi$

\begin{tabular}{|l|c|c|c|c|}
\hline \multirow{2}{*}{ Coast } & \multicolumn{2}{|c|}{ Light minerals } & \multicolumn{2}{c|}{ heavy minerals } \\
\cline { 2 - 5 } & range & mean value & range & mean value \\
\hline AG. VARVARA & $0.000-100.000$ & 30.799 & $0.000-100.000$ & 69.201 \\
\hline R. VOULGARI & $0.000-10.150$ & 6.167 & $89.850-100.000$ & 93.833 \\
\hline
\end{tabular}


The dominant heavy minerals are mainly magnetite, hornblend, augite and biotite. The participation percentage of the magnetite fluctuates between $25 \%$ and $60 \%$, while that of the hornblend is higher than $10 \%$. The minerals haematite and limonite participate at a lower percentage not higher than $10 \%$ and $5 \%$ respectively.

The light minerals identified in the sand of the Ag. Varvara coast (Table 7) are plagioclase which are dominant $(65 \%)$, the quartz, participating with a significant percentage $(15 \%$-30\%), the Kfeldspar with a small percentage between $1 \%$ and $15 \%$ and the clay minerals, illite, chlorite, and smectite, probably products from the weathering of the feldspars.

All the identified minerals are products from the erosion of the volcanic rocks (mainly rhyolites, dacites, andesites) in the surrounding area and therefore they reflect their petrology.

The high percentage of plagioclases in the sand of the Ag. Varvara coast, as well as the presence of ferromagnesian heavy minerals at a considerable percentage - that is minerals unstable during the erosion - characterizes the sand as an immature sediment from a mineralogical point of view. This means that the natural erosion plays a significant role in the erosion of the minerals of the surrounding ground and thus the chemical processes needed for the formation of mature mineralogically sediments are restricted. This opinion is enhanced by the presence of a small percentage of the secondary clay-minerals illite, chlorite and smectite.

Table 7 - Qualitative mineralogical composition of sand samples of Ag. Varvara coast

\begin{tabular}{|c|c|c|c|c|c|c|c|}
\hline \multicolumn{8}{|c|}{ Light mineral } \\
\hline Coast & 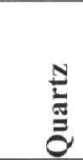 & 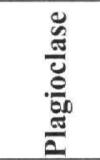 & $\frac{i}{\frac{i}{2}}$ & 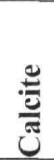 & $\stackrel{\mathscr{\Xi}}{\Xi}$ & 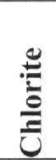 & 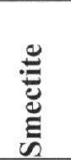 \\
\hline $\begin{array}{l}\text { AG. VARVARA } \\
\text { RIVER VOULGARI }\end{array}$ & ++ & $\begin{array}{l}++++ \\
++++\end{array}$ & + & + & + & + & + \\
\hline $\begin{array}{l}++++[65<\%] \\
+++[30-65 \%] \\
++[15-30 \%] \\
+[1-15 \%]\end{array}$ & \multicolumn{7}{|c|}{$\begin{array}{l}* \text { The number of the symbols }+ \text { gives the approximately minerals content } \\
\text { in percentage at the fractions } 2-3 \Phi .\end{array}$} \\
\hline
\end{tabular}

\section{Conclusions}

From the geomorphologic-morphotectonic analysis of the drainage network and the catchment area of the Voulgaris river, it is concluded that the drainage network is in an unstable dynamically balanced state, as indicated by the relatively high mean value of the bifurcation ratio. This is due to the elevation of the relief attributed to the neotectonic processes taking place in the greater area under investigation, which may be amplified by a possible turgidity resulting from volcanic action. The elevation of the relief, results in an in depth erosion of the lower order streams of the drainage network and the substantial supply of materials to the Voulgaris main river bed. This is indicated both by the high value of the bifurcation ratio and the length ratio of the higher orders streams $\left(\mathrm{R}_{\mathrm{B}(4 / 5)}=6,00 \& \mathrm{R}_{\mathrm{L}(5 / 4)}=6,37\right)$ and also by the positive deviation value of the fourth order's number of streams $(34,50 \%)$. It is also noted that Voulgaris river bed has a length which is more than double than of the ideal one (length deviation of the $5^{\text {th }}$ order stream $=237,13 \%$ ), meaning that the river bed is able to receive a significant quantity of transported materials. The big length of the river bed is due to its shift towards the west, especially the shift of the central part, hence the increase of its course.

However, the shape of the hypsometric curve indicates that the catchment area is not in an advanced denudation stage, since part of the materials from the top of the basin, where the supply is substantial due to intense erosion, is being transported and deposited on the bottom of the basin. 
The percentage of the material being transported and deposited on the coast is even less. Therefore, the catchment area is still substantially capable in supplying material to the coast. The data from the sedimentary analysis also point to the fact that the sullpy of materials to the coast is small.

Summarizing, it is concluded that although the supply of materials to the river bed is substantial, only a small percentage of that is transported to the coast. This is attributing to the diminished transportation capability of the river. Other factors contributing to this are the longer than expected length of the river bed, its small slopes, an the low rainfall level in the area.

\section{References}

Alexouli-Livaditi, A., Livaditis, G., and Lykoudi, E., 2002. Investigation and delineation of areas of intense erosion and product of wasting materials at Lesvos island, Greece. $6^{\text {th }}$ Panhellenic Geographical Congress of the Geographical Society of Greece, II, 303-310.

Alexouli-Livaditi, A., and Lykoudi, E., 2002. Qantitative geomorphological study of Lesvos Island drainage network (Greece), Bulletin of the Geological Society of Greece, XXXV-2003, 518.

Cox, R.T., 1994. Analysis of drainage basin symmetry as a rapid technique to identify areas of possible Quaternary tilt-block tectonics: an example from the Mississippi Embayment, Geol. Soc. of Am. Bull., 106, 571-581.

Folk, R., 1974. Petrology of sedimentary rocks. Hemphill Pub. Austin, Texas.

Hare, P.W., and Gardner, T.W., 1985. Geomorphic indiators of vertical neotectonism along converging plate margins, Nicoya Peninsula, Costa Rica. In M. Morisawa and J.T. Hack (eds), Tectonic Geomorphology, Proc. of the 15th Annual Binghamton Geomorphology Symbosium, Allen \& Unwin, Boston.

Hecht, J., 1972. I.G.M.E. geological map, 1:50.000, sheets: Mythimna.

Hecht, J., 1975. I.G.M.E. geological map, 1:50.000, sheets: Eresos.

Horton, R.E., 1945. Erosional development of streams and their drainage basins; Hydrophysical approach to quantitative morphology, Bull. Geol. Soc. of America, 56, 275-370.

Karras, G., 1973. Climatic classification of Greece according to Thornthwait, Phd. N.K.U. A. Athens.

Katsikatsos, G., Mataragas, D., Migiros, G., and Triantaphyllis, E., 1982. Geological Study of Lesbos Island. I.G.M.E. Internal report.

Katsikatsos, G., Migiros, G., Triantaphylli, M., and Mettos, A., 1986. Geological structure of Internal Hellenides (E. Thessaly - SW Macedonia, Euboea - Attica - Northern Cyclades Islands and Lesbos), I.G.M.E. Geological and Geophysical Research, 191-212.

Leopold, L.B., and Langbein, W.B., 1962. The concept of entropy in landscape evolution, U.S.G.S. Prof. Paper 500-A, 1-20pp.

Lykoudi, E., and Zarris, D., 2004. The influence of drainage network formation and characteristics over a catchment's sediment yield, Proceedings: Second International Conference on Fluvial Hydraulics - RiverFlow 2004, University of Napoli - Federico II, Naples, Italy, 23 - 25 June, 793-800pp.

Pe-Piper, G., 1978. The Cenozoic Volcanic Sequence of Lesbos, Greece, PhD, Patra.

Shreve, L., 1966. Statistical law of stream numbers, Jour. Geol., 74, 17-37. 
Spencer, D.W., 1963. The intepretation of grain-size distribution curves of clastic sediments, Jour. Sedim. Petr., 33, 180-190.

Strahler, A., 1952. Hypsometric (area-altitude) analysis of erosional topography, Geol. Soc. Amer. Bull., 63, 1117-1142.

Strahler, A., 1957. Quantitative analysis of watershed geomorphology, American Geophysical Union Transactions, 38(6), 913-920. 